УДК 630

\title{
ПРАВОВОЕ РЕГУЛИРОВАНИЕ БОРТНИЧЕСТВА КАК ТРАДИЦИОННОГО РОССИЙСКОГО ЛЕСНОГО ПРОМЫСЛА
}

\author{
Никифоров Сергей Александрович \\ к.и.н., доцент кафедры истории \\ и социально-культурного сервиса \\ Юго-Западный государственный университет
}

Аннотация: в статье раскрываются особенности использования лесов для заготовки меда диких пчел, а также проведен анализ законодательных норм, направленных на защиту бортничества как важного промысла.

Ключевые слова: лес, бортничество, пчеловодство, законодательное регулирование.

Финансирование: Публикащия подготовлена в рамках выполнения государственного задания на 2021 2. "Трансформаџия частного и публичного права в условиях эволюционирующих личности, обществва и государства» (№ 0851-2020-0033).

\section{LEGAL REGULATION OF BORTNICHESTVO AS A TRADITIONAL RUSSIAN FORESTRY}

Nikiforov Sergey Alexandrovich

\begin{abstract}
: the article reveals the features of the use of forests for harvesting honey of wild bees, as well as the analysis of legislative norms aimed at protecting bee-keeping as an important fishery.

Keywords: forest, bee-keeping, beekeeping, legislative regulation.

Acknovledgements: The publication was prepared as part of the implementation of the state task for 2021 "Transformation of private and public law in an evolving individual, society and state" (№ 0851-2020-0033).
\end{abstract}




\section{ПЕРЕДОВОЕ РАЗВИТИЕ СОВРЕМЕННОЙ НАУКИ КАК ДРАЙВЕР РОСТА ЭКОНОМИКИ И СОЦИАЛЬНОЙ СФЕРЫ}

Сбор меда диких пчел, живущих в дуплах деревьев в лесу, называют бортничеством. Термин восходит к слову «бор», что значит «сосновый лес». Бортничеством также называют пчеловодство, организованное в лесной зоне. Мед, полученный на пасеке в лесной местности, считается элитным продуктом среди других разновидностей этого лакомства.

Бортничество имело большое значение для хозяйства Руси. Богатая лесами и степями наша страна прекрасно подходила для пчеловодства. Мед использовался как в качестве самостоятельного пищевого продукта, так и основы для приготовления различных блюд, напитков, лекарств. Из воска делали свечи, замазки, пластыри. Спрос на мед и воск были высоким как на внутреннем, так и на внешнем рынках.

Бортничество, определенно, было профессиональным занятием. Бортник имел исключительное право на добычу меда в дуплах определенных деревьев, на которые были нанесены соответствующие метки. Добыча меде была не под силу обывателям, так как требовала специфических знаний, значительных трудозатрат и готовности идти на риск. Бортнику было необходимо регулярно обходить значительную территорию, передвигаясь в лесной чаще в отсутствие дорог транспортировать мед и воск. Бортник должен был с риском для жизни и здоровья забираться на высокие деревья, где располагались дупла пчел.

Русский историк В.О. Ключевский в книге «Сказания иностранцев о Московском государстве» описывает случай, характеризующий как богатство русских лесов медом, так и опасность бортничества. «Русский посол, рассказывал Иовию, как один крестьянин, опустившись в дупло огромного дерева, увяз в меду по самое горло; тщетно ожидая помощи в глухом лесу, он два дня питался одним медом и выведен был из этого затруднительного положения медведем, который опустился задними лапами в то же дупло: поселянин схватил его руками за хвост и закричал так громко, что испуганный медведь быстро выскочил из дупла и вытащил вместе с собой крестьянина» [1, с. 141]. Описывая этот курьез, В.О. Ключевский обозначил богатые медом регионы России: «Мед в значительном количестве шел из Мордвы и Кадома, вблиз земли черемис, также из областей Северской, Рязанской, Муромской, Казанской и Смоленской» [1, с. 141].

Исследователь лесного права В. Врангель отмечал тот факт, что бортничество во многом определяло общее направление постановлений по лесной части в XVII в. и в более ранний период. Так, в числе издержек поташных и смольчужных заводов приводится то, что промышленники портят 


\section{ПЕРЕДОВОЕ РАЗВИТИЕ СОВРЕМЕННОЙ НАУКИ КАК ДРАЙВЕР РОСТА ЭКОНОМИКИ И СОЦИАЛЬНОЙ СФЕРЫ}

бортные деревья, а дымом истребляют и пугают пчел. Поэтому чаще всего эти направления лесного промысла приносились в жертву пчеловодству «освященному веками» [2, с. 9].

Бортничество, как и охота, имело настолько важное значение, что этот промысел упоминаются в первых нормативно-правовых документах, касающихся использования лесных ресурсов. Несколько статей о «борти» содержатся в Русской Правде. В нормативно-правовых актах более позднего периода зафиксированы факты как совершенствования бортного промысла, так усложнения социально-экономических отношений. В качестве примера приведем документ об обращении в 1587 г. крестьянина Унженского уезда о передаче ему в аренду лесных угодий для пчеловодства и расположенных за p. Унжей верст двадцать или тридцать, а за оброчное его содержание он обязывался уплачивать в год пуд меда да пошлины с пуда 5 денег [3, с. 8].

В XVII в. значительный доход бортничество приносило крупным вотчинникам. Так, бортничество было важной составляющей хозяйства боярина Б.И. Морозова [4, с. 56].

Законодательные меры, направленные на защиту бортнического промысла от преступных посягательств, содержатся в Соборном уложении (ст. $218,219)$. Так, статья 218 гласит: «А будет кто в чюжом же угодье испортит бортное дерево, корень подсечет или подожжет, или каким-нибудь обычаем какую поруху учинит нарочно, и в том на него будут челобитчики, и сыщется про то допряма, что он такое дело учинил, и за насильство на нем по суду и по сыску доправить за бортное дерево со пчелами три рубли, а безо пчел, в котором дереве напереть того пчелы были, полтора рубли, а в котором дереве борть была зделана, а пчел не бывало, и за то двадцать пять алтын, за кряжь невыделаной по двенатцати алтын по три деньги, сколько их ни испортит» [5, с. 56]. Статьи 239, 240, 243 Соборного уложения устанавливают правоотношения между сособственниками земель, на которых располагаются леса и владельцами деревьев, служащих для добычи меда [5, с. 58-59]. При этом государство гарантировало защиту собственности бортников.

Сбор государственных налогов в натуральном виде (медом) с лесных бортных угодий продолжался до XVIII в. Петр I неоднократно пытался вместо натуральных податей взимать денежный налог, но изменить устоявшуюся традиция было непросто - государство по-прежнему получало мед. «И только в 1724 г. постановлено распродать мед, накопившийся с малороссийских 


\section{ПЕРЕДОВОЕ РАЗВИТИЕ СОВРЕМЕННОЙ НАУКИ КАК ДРАЙВЕР РОСТА ЭКОНОМИКИ И СОЦИАЛЬНОЙ СФЕРЫ}

городов, и велено впредь брать десятый улей, а деньгами по 60 коп., а у кого менее 10 ульев, брать с каждого по 6 коп.» [6, с. 26].

В России, наряду с бортничеством, существовало и улейное пчеловодство. До XVIII века они развивались параллельно. Однако, в пчеловодческом хозяйстве России в XVII в. произошел кризис. К концу века резко сократилось количество лесов, а вместе с этим и медоносных угодий. Кроме того, себестоимость дикого меда существенно выше собираемого на обычной пасеке. Это связано с тем, что пасечник качает мед в течение всего сезона. Дикий же мед собирают один раз в год- осенью. К этому периоду пчелы уже заготовили его для себя на зиму. У диких пчел забирают только часть меда, часть оставляют, чтобы пчелы могли перезимовать. Негативное влияние на пчеловодства также оказало распространение сахара, также пришедшееся на XVII в. Спрос на мед, а вместе с тем и цена упали. Сложность и снижение доходность бортничества привели к переходу в XVIII в. к улейному и пасечному способам пчеловодства.

В настоящее время интерес к бортничеству возрождается. Мед диких пчел воспринимается как полезный для здоровья, экологически чистый продукт. При этом правовой режим добычи меда диких пчел не установлен, юридический механизм определения принадлежности бортевых деревьев в России отсутствует [7].

\section{Список литературы}

1. Ключевский В.О. Сказания иностранцев о Московском государстве. Вступительная статья и комментарии А.Н. Медушевского. - М.: Прометей, 1991. - $341 \mathrm{c}$.

2. Врангель В. История лесного законодательства Российской Империи. СПб.: Тип. Фишера,1841. - 153 с.

3. Шелгунов Н.И. История русского лесного законодательства. - СПб.: тип. М-ва гос. имуществ, 1857. - 378 с.

4. Муравьева Л.А. Российское предпринимательство в XVII веке // Дайджест-Финансы. - 2005 - № 3 (123). - С. 54-63.

5. Соборное Уложение 1649. Текст. Комментарии. - Л.: Издательство «Наука», 1987. - 448 с. 
6. Рыбалкин А.И. Источники и историография лесного дела в Российской империи: монография - Воронеж: ФГБОУ ВПО "Воронежский гос. аграрный ун-т им. Петра I", 2013. - 206 с.

7. «Деревья передают по наследству» Как россияне сохраняют почти исчезнувший промысел - сбор меда диких пчел // Сайт LENTA.RU [Электронный pecypc] URL: https://lenta.ru/articles/2021/09/04/bortnichestvo/ (дата обращения: 15.11.2021). 